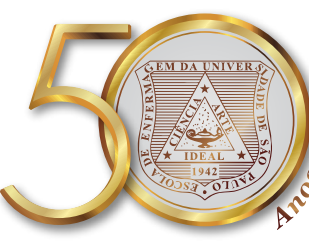

\title{
Nursing interventions with people with obesity in Primary Health Care: an integrative review
}

\author{
Intervenções do enfermeiro às pessoas com obesidade na Atenção Primária à Saúde: revisão integrativa \\ Intervenciones del enfermero en las personas con obesidad en la Atención Primaria de Salud: \\ revisión integrativa
}

Vanessa Augusta Souza Braga1, Maria Cristina Pinto de Jesus ${ }^{2}$, Claudete Aparecida Conz ${ }^{1}$, Renata Evangelista Tavares ${ }^{1}$, Marcelo Henrique da Silva ${ }^{3}$, Miriam Aparecida Barbosa Merighi ${ }^{4}$

How to cite this article:

Braga VAS, Jesus MCP, Conz CA, Tavares RE, Silva MH, Merighi MAB. Nursing interventions with people with obesity in Primary Health Care: an integrative review. Rev Esc Enferm USP. 2017;51:e03293. DOI: http://dx.doi.org/10.1590/S1980-220X2017019203293

${ }^{1}$ Universidade de São Paulo, Escola de Enfermagem, Programa de Pós-Graduação em Enfermagem, São Paulo, SP, Brazil.

${ }^{2}$ Universidade Federal de Juiz de Fora, Faculdade de Enfermagem, Departamento de Enfermagem Básica, Juiz de Fora, MG, Brazil.

${ }^{3}$ Secretaria Municipal de Saúde, Estratégia Saúde da Família, Juiz de Fora, MG, Brazil.

${ }^{4}$ Universidade de São Paulo, Escola de Enfermagem, Departamento MaternoInfantil e Psiquiátrica, São Paulo, SP, Brazil.

\begin{abstract}
Objective: Identify the knowledge produced on nursing interventions with people suffering from obesity in Primary Health Care. Method: Integrative literature review of publications indexed in the databases: CINAHL, LILACS, MEDLINE, SciELO, SCOPUS and WEB OF SCIENCE, between 2011 and 2016. Results: Thirty-three articles were selected. The knowledge produced covered two themes: "Counseling aimed at weight control and promotion of healthy lifestyle habits" and "Perception of Primary Health Care nurses regarding interventions with people with obesity." Conclusion: The results may help prompt reflections on professional training, management, and health services in terms of the relevance of nurses working with people suffering from obesity, with the support of digital technologies, motivational techniques, and nursing consultations. This could enhance their activities in the multiprofessional teams in which they participate at this healthcare level.
\end{abstract}

DESCRIPTORS

Obesity; Nursing Care; Primary Care Nursing; Review. 


\section{INTRODUCTION}

Obesity is a public health problem in both developed and developing countries, and constitutes an important risk factor for the emergence of chronic noncommunicable diseases ${ }^{(1)}$. The World Health Organization (WHO) estimated that, in 2014, the number of overweight people totaled more than 1.9 billion adults, of whom 600 million suffered from obesity, corresponding to $13 \%$ of the world's adult population. In relation to children under the age of five, the estimate was 41 million $^{(1)}$.

Data from VIGITEL 2015 (Surveillance of Risk and Protection Factors for Chronic Diseases by Telephone Inquiry - Vigilância de Fatores de Risco e Proteção para Doenças Crônicas por Inquérito Telefônico) revealed frequent overweight among the Brazilian adult population, which had increased in relation to the results of the VIGITEL 2014 survey, rising from $52.5 \%$ to $53.9 \%$. The increase was greater among men (57.6\%) than women (50.8\%). Obesity affected $18.9 \%$ of the population, compared to $15 \%$ in $2010^{(2)}$.

Given these obesity prevalence projections, Primary Health Care (PHC) plays an essential role in managing the care of people within local regions, through the work of multidisciplinary teams and, especially, the role of nurses ${ }^{(3)}$. In this care context, actions for health promotion, prevention, and control of diseases resulting from obesity should be routine. These actions should focus on the difficulties related to managing this chronic disease and ensuring that users suffering from obesity, as well as those at risk of developing it, receive the necessary support ${ }^{(4)}$.

In Brazil, at this level of health care, the duties of nurses include: establish the risk stratification for obesity; carry out health promotion activities with social participation; support self-care; and promote delivery of care to individuals who are already obese, especially if there are associated comorbidities. They should also monitor those who are undergoing obesity-related surgical procedures ${ }^{(3)}$.

A systemic literature review examined the work of PHC nurses who care for individuals with chronic diseases in the United Kingdom, United States, Finland, Holland, and New Zealand. Its results pointed out the effectiveness of lifestyle-focused interventions by these $\mathrm{PHC}$ professionals, aimed at positive changes in behaviors associated with the prevention of chronic diseases. The actions carried out the most by the nurses were weight, blood pressure and cholesterol control, encouragement of healthy eating habits, and engaging in physical activity ${ }^{(5)}$.

In the United Kingdom, Netherlands and Scandinavian countries, PHC nurses have a defined role in counseling people about healthy lifestyles for the purpose of weight control. In the United States, the activities of PHC nurses with people suffering from obesity have still not been clearly defined, and these professionals operate according to their own initiative. Although nurses referred to lack of time as a barrier, they showed themselves to be more available than physicians to provide this counseling. It was noted that the frequency of actions with people with obesity had increased in recent years ${ }^{(6)}$.
In Brazil, scientific production related to the actions of PHC nurses with people suffering from obesity is still in the early stages, despite the relevance of the theme for the population's health care and expansion of the coverage of the Family Health Strategy, considered a tool of the Brazilian Unified Health System (SUS - Sistema Único de Saúde) for the qualification and consolidation of PHC. The objective of the present study was to identify the knowledge produced regarding the work of Primary Health Care nurses with people with obesity.

It is important to gather national and international scientific evidence about the work of PHC nurses with people suffering from obesity in order to help improve the nursing care given to this population and increase knowledge in the field of nursing.

\section{METHOD}

This was an integrative literature review that enabled collection, critical assessment, and synthesis of knowledge on the theme being investigated. In addition, it helped identify research results that provide input for professional decisions in clinical practice, as well as for developing future studies ${ }^{(7)}$.

The present integrative review was carried out in six stages: selection of the study question; establishment of the inclusion and exclusion criteria (sample selection); definition of the information to be extracted from the selected articles (categorization of the studies); analysis of the information; interpretation of the results; and presentation of the review (synthesis of the knowledge) ${ }^{(7)}$.

To guide the search for scientific publications, the question of this study was formulated based on the PICO strategy ${ }^{(8)}$ : What knowledge has been produced about nursing interventions with people with obesity in PHC? Where $\mathrm{P}=$ people with obesity; $\mathrm{I}=$ intervention of nurses; $\mathrm{C}=$ primary health care; and $\mathrm{O}=$ knowledge produced.

The publications were collected between January and July 2017 by the main researcher and an independent reviewer, through an electronic search in the following databases: Cumulative Index to Nursing and Allied Health Literature (CINAHL), Latin America and Caribbean Center on Health Sciences Information (LILACS), Medical Literature Analysis and Retrieval System Online (MEDLINE), Scientific Electronic Library Online (SciELO), Scopus Info Site (SCOPUS) and WEB OF SCIENCE. To perform the search, Health Sciences Descriptors (DeCS) and Medical Subject Headings (MeSH), keywords and CINAHL terms were used, as shown in Chart 1.

The inclusion criteria for the search in all the databases were: articles addressing PHC nursing interventions with people with obesity; written in English, Spanish and Portuguese; published between 2011 and 2016; containing the terms collected in the title, descriptors or abstracts; available in their full versions; and online for free. The time period was based on the importance of identifying studies conducted after the General Assembly of the United Nations held in the United States in September 2011, where one of the nine global goals to be reached by 2025 was fighting obesity ${ }^{(9)}$. 
Chart 1 - Search strategy for articles found in the databases - São Paulo, 2017.

\begin{tabular}{|c|c|}
\hline Database & Search strategy \\
\hline SCOPUS & Keywords - "nurses" OR "health personnel" OR "nurse practitioners" AND "primary health care" AND "obesity" \\
\hline CINAHL & CINAHL terms - "nurses" OR "health personnel" OR "nurse practitioners" AND "primary health care" AND "obesity" \\
\hline MEDLINE & $\begin{array}{c}\text { Descriptors (MeSH) - "nurses" OR "health personnel" OR "nurse practitioners" OR "nursing" AND "obesity" AND "primary } \\
\text { health care" OR "primary care" }\end{array}$ \\
\hline LILACS & Descriptors (DeCS) - "nurses" OR "health personnel" OR "nurse practitioners" AND "primary health care" AND "obesity" \\
\hline WEB OF SCIENCE & $\begin{array}{c}\text { Keywords - "nurses" OR "health personnel" OR "nurse practitioners" OR "nursing" AND "primary health care" OR "primary } \\
\text { care" AND "obesity" }\end{array}$ \\
\hline SCIELO & Keywords - "nurses" OR "health personnel" OR "nurse practitioners" AND "primary health care" AND "obesity" \\
\hline
\end{tabular}

Theses, dissertations, case studies, editorials, letters to the editor and duplicates found in more than one database and gray literature were excluded. Figure 1 presents a diagram of the results of applying the inclusion and exclusion criteria to the productions identified in the search strategy.

Based on the composition of the sample, a database was created using Microsoft Office Excel 2016. This made it possible to organize and compile the following information from the selected studies: title of the article, first author's profession, year of publication, country, database, name of the journal, nationality of the study participants, study design, intervention, and outcome. The data obtained was distributed into four instrumental tables and thematic categories grouped by similarity of content. The results were interpreted based on literature related to the study theme.

\section{RESULTS}

Most of the articles were published between 2012 and 2014 , representing $66.7 \%$ of the total publications. The countries that generated the most articles on PHC nursing interventions with people with obesity were England, the United States, Holland, and Sweden. The journal with the highest number of publications on the theme was BioMed Central Nursing (21.2\%). In terms of the first author, the professionals that published the most were physicians (27.3\%), followed by nurses (24.2\%). The most frequent study designs were observational, with 19 studies (57.6\%), followed by clinical trials, with 11 studies (33.3\%) and quasi-experimental, with three studies (9.1\%).

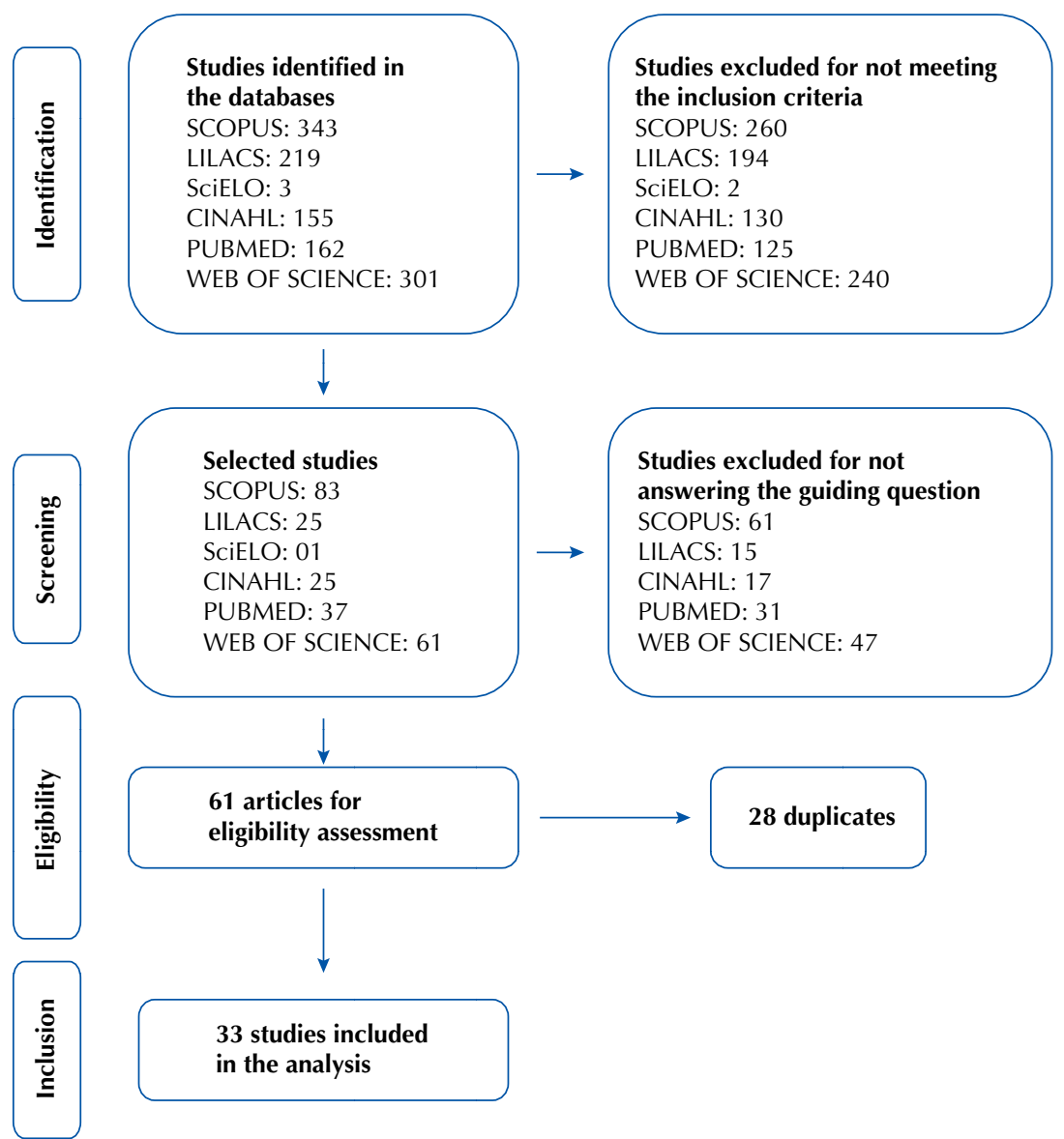

Figure 1 - Diagram of the results of applying the study's inclusion and exclusion criteria - São Paulo, 2017. 
As for the content of the articles, the knowledge produced encompassed two main themes: Counseling aimed at weight control and promotion of healthy lifestyle habits and
Perception of Primary Health Care nurses regarding interventions with people with obesity. The synopses of the articles selected for the study are presented in Chart 2.

Chart 2 - Synopses of the articles selected for the integrative review - São Paulo, 2017.

\begin{tabular}{|c|c|c|c|}
\hline $\begin{array}{l}\text { Authorship/ } \\
\text { Country }\end{array}$ & $\begin{array}{l}\text { Design / } \\
\text { Participants }\end{array}$ & Interventions & Outcome \\
\hline $\begin{array}{l}\text { Dillen et al., } \\
2014^{(10)} \\
\text { Holland }\end{array}$ & $\begin{array}{l}\text { Observational, } \\
\text { descriptive } \\
n=100\end{array}$ & $\begin{array}{l}\text { Analysis of the content of advice given to people } \\
\text { with obesity during nursing consultations. }\end{array}$ & $\begin{array}{c}\text { The main categories for each type of advice were: lose } \\
\text { weight, eat less fat and be physically active. }\end{array}$ \\
\hline $\begin{array}{l}\text { Laws et al., } \\
2015^{(11)} \\
\text { Australia }\end{array}$ & $\begin{array}{l}\text { Observational, } \\
\text { mixed methods } \\
\quad \mathrm{n}=56\end{array}$ & $\begin{array}{l}\text { Survey and semi-structured interviews with nurses } \\
\text { on advice for obesity given during routine nursing } \\
\text { consultations with children from } 0 \text { to } 5 \text { years old. }\end{array}$ & $\begin{array}{l}\text { The nurses never/rarely used growth graphs to identify } \\
\text { children at risk of overweight/obesity. Most gave advised on } \\
\text { nutrition, and less than half promoted physical activity and } \\
\text { routinely discussed sedentary behavior. }\end{array}$ \\
\hline $\begin{array}{l}\text { Bogt et al., } \\
2011^{(12)} \\
\text { Holland }\end{array}$ & $\begin{array}{l}\text { Clinical trial, } \\
\text { randomized, } \\
\text { controlled } \\
\mathrm{n}=457\end{array}$ & $\begin{array}{l}\text { Interventions carried out by nurses to prevent } \\
\text { weight regain in adults, through guidelines via } \\
\text { software, compared with conventional guidelines } \\
\text { given by physicians, over a period of three years. }\end{array}$ & $\begin{array}{c}\text { There was no significant weight change difference in } \\
\text { the two groups. In both, } 60 \% \text { of the participants were } \\
\text { able to maintain the weight after three years. There was } \\
\text { a significant difference in blood glucose reduction in the } \\
\text { group guided by nurses, but not for blood pressure and } \\
\text { lipid levels. }\end{array}$ \\
\hline $\begin{array}{l}\text { Barte et al., } \\
2012^{(13)} \\
\text { Holland }\end{array}$ & $\begin{array}{l}\text { Quasi- } \\
\text { experimental, } \\
\text { intervention in the } \\
\text { community } \\
\mathrm{n}=214\end{array}$ & $\begin{array}{l}\text { The participants in the intervention group (adults) } \\
\text { received a structured questionnaire seven months } \\
\text { after the end of the intervention for lifestyle } \\
\text { changes. Four nursing consultations and one } \\
\text { phone call took place. }\end{array}$ & $\begin{array}{c}\text { The overall satisfaction of the participants was high, } \\
\text { especially among those with low levels of education. } \\
\text { Nurses were viewed as motivators for learning about and } \\
\text { maintaining a healthy lifestyle. }\end{array}$ \\
\hline $\begin{array}{l}\text { Dillen et al., } \\
2015^{(4)} \\
\text { Holland }\end{array}$ & $\begin{array}{l}\text { Observational, } \\
\text { descriptive } \\
n=100\end{array}$ & $\begin{array}{l}\text { The quality of counsel given in nursing } \\
\text { consultations about weight loss was assessed. }\end{array}$ & $\begin{array}{l}\text { Nurses focused on the behavior of people with obesity, } \\
\text { using motivational communication. They rarely tackled } \\
\text { obstacles and ensured weight control support. }\end{array}$ \\
\hline $\begin{array}{l}\text { Riiser et al., } \\
2014^{(14)} \\
\text { Norway }\end{array}$ & $\begin{array}{l}\text { Clinical trial, } \\
\text { randomized, } \\
\text { controlled } \\
\mathrm{n}=120\end{array}$ & $\begin{array}{l}\text { Participants were aged } 13 \text { to } 15 \text { years. The } \\
\text { intervention group received a } 12 \text {-week access } \\
\text { to an online program that provided advice on } \\
\text { exercise based on the theory of self-determination } \\
\text { and motivational interviews. The control group } \\
\text { received standard follow-up from the nurses. }\end{array}$ & $\begin{array}{l}\text { The intervention had a slight impact on cardiorespiratory } \\
\text { fitness and a moderate impact on quality of life. The } \\
\text { intervention group had a significantly lower increase in } \\
\text { body mass index (BMI) in relation to the control group. }\end{array}$ \\
\hline $\begin{array}{l}\text { Isma et al., } \\
2013^{(15)} \\
\text { Sweden }\end{array}$ & $\begin{array}{l}\text { Observational, } \\
\text { phenomenological } \\
\qquad n=18\end{array}$ & $\begin{array}{c}\text { Open interviews with nurses to understand their } \\
\text { views on preventive approaches to overweight and } \\
\text { obesity in childhood. }\end{array}$ & $\begin{array}{l}\text { The nurses viewed their work as difficult due to lack of } \\
\text { standardization in guidelines for obesity and overweight } \\
\text { prevention and management. The organization and } \\
\text { management of the services were also deficient. }\end{array}$ \\
\hline $\begin{array}{l}\text { Teixeira et } \\
\text { al., } 2015^{(16)} \\
\text { Portugal }\end{array}$ & $\begin{array}{c}\text { Observational, } \\
\text { descriptive } \\
\mathrm{n}=44\end{array}$ & $\begin{array}{c}\text { Semi-structured interviews with nurses, physicians, } \\
\text { and nutritionists regarding the discourse of health } \\
\text { professionals when faced with obesity. }\end{array}$ & $\begin{array}{l}\text { The professionals had negative beliefs and attitudes in } \\
\text { relation to people with obesity. Nutritionists and nurses felt } \\
\text { they were able to influence the motivation of these people. }\end{array}$ \\
\hline $\begin{array}{l}\text { Robinson et } \\
\text { al., } 2013^{(17)} \\
\text { Australia }\end{array}$ & $\begin{array}{l}\text { Observational, } \\
\text { descriptive } \\
n=59\end{array}$ & $\begin{array}{l}\text { Questionnaire and semi-structured interviews to } \\
\text { understand the practices and attitudes of nurses in } \\
\text { relation to child obesity prevention. }\end{array}$ & $\begin{array}{c}\text { The nurses described prevention work as pleasant. } \\
\text { Seventy percent were interested in getting more involved } \\
\text { in children's health tests, and 85\% expressed interest in } \\
\text { receiving training in child obesity prevention. }\end{array}$ \\
\hline $\begin{array}{l}\text { Tucker et al., } \\
2013^{(18)} \\
\text { USA }\end{array}$ & $\begin{array}{l}\text { Quasi- } \\
\text { experimental, } \\
\text { intervention in the } \\
\text { community } \\
\mathrm{n}=130\end{array}$ & $\begin{array}{l}\text { Intervention through motivational interviews } \\
\text { carried out by nurses to reduce excess pediatric } \\
\text { weight compared to standard clinical care. }\end{array}$ & $\begin{array}{l}\text { The effects of the intervention included increased daily } \\
\text { consumption of fruits/vegetables, more physical activity } \\
\text { and fewer hours watching television. }\end{array}$ \\
\hline $\begin{array}{l}\text { Jarl et al., } \\
2014^{(19)} \\
\text { USA }\end{array}$ & $\begin{array}{l}\text { Quasi- } \\
\text { experimental, } \\
\text { pre- and post- } \\
\text { intervention time } \\
\text { series } \\
\mathrm{n}=45\end{array}$ & $\begin{array}{c}\text { Actions implemented during two months with people } \\
\text { suffering from obesity associated with hypertension. } \\
\text { These actions included addressing dietary issues and } \\
\text { lifestyle changes. The nursing intervention consisted } \\
\text { of three in-person group meetings and two phone } \\
\text { calls for personal counseling. }\end{array}$ & $\begin{array}{c}\text { The participants made statistically significant improvements } \\
\text { in their diets and lifestyle scores, in addition to losing a } \\
\text { significant amount of weight (mean of } 1.6 \mathrm{~kg} \text { lost) during } \\
\text { the two-month intervention. }\end{array}$ \\
\hline $\begin{array}{l}\text { Karnon et al., } \\
2013^{(20)} \\
\text { Australia }\end{array}$ & $\begin{array}{l}\text { Observational, } \\
\text { descriptive } \\
n=175\end{array}$ & $\begin{array}{l}\text { Analysis of clinical data and outcomes (weight, } \\
\text { BMI, obesity-related complications) and use of } \\
\text { resources (primary, pharmaceutical and hospital } \\
\text { care) to assess the cost-effectiveness of actions by } \\
\text { nurses with people suffering from obesity. }\end{array}$ & $\begin{array}{l}\text { Low involvement of nursing professionals in clinical } \\
\text { activities with patients with obesity was identified. When } \\
\text { nurses were involved, care costs were lower and more } \\
\text { people lost weight. }\end{array}$ \\
\hline $\begin{array}{l}\text { Nolan et al., } \\
2012^{(21)} \\
\text { England }\end{array}$ & $\begin{array}{l}\text { Observational, } \\
\text { descriptive } \\
n=22\end{array}$ & $\begin{array}{l}\text { Semi-structured interviews with nurses regarding } \\
\text { the response to problems of people with } \\
\text { obesity and the legitimacy of the work of these } \\
\text { professionals. }\end{array}$ & $\begin{array}{l}\text { In terms of positive factors, the nurses listed links with } \\
\text { patients, participation in training, and support for investing } \\
\text { in obesity management. The negative factors included } \\
\text { lack of priority in obesity management, time and clarity in } \\
\text { relation to protocols and their work in practice. }\end{array}$ \\
\hline $\begin{array}{l}\text { Blackburn } \\
\text { et al., } \\
2015^{(22)} \\
\text { England }\end{array}$ & $\begin{array}{l}\text { Observational, } \\
\text { descriptive } \\
n=34\end{array}$ & $\begin{array}{l}\text { Semi-structured interviews to explore points of } \\
\text { view, opinions, and experiences of nurses for } \\
\text { initiating discussions on weight control. }\end{array}$ & $\begin{array}{l}\text { The following barriers were identified: limited } \\
\text { understanding of obesity care, concern with the negative } \\
\text { consequences of excess weight, and lack of time and } \\
\text { resources to propose an effective alternative. }\end{array}$ \\
\hline
\end{tabular}

Continue 


\begin{tabular}{|c|c|c|c|}
\hline $\begin{array}{l}\text { Yardley et al., } \\
2014^{(23)} \\
\text { England }\end{array}$ & $\begin{array}{l}\text { Clinical trial, } \\
\text { randomized, } \\
\text { controlled } \\
\mathrm{n}=179\end{array}$ & $\begin{array}{l}\text { The adult patients were divided into four } \\
\text { intervention groups: normal care }(n=43) \text {; a group } \\
\text { that received regular nursing support }(n=47) ; \text { a } \\
\text { group with web-based intervention only }(n=45) ; \\
\text { and a group with web-based intervention and } \\
\text { basic nursing support }(n=44) \text {. }\end{array}$ & $\begin{array}{l}\text { At } 12 \text { months, the mean weight loss was } 2.44 \mathrm{~kg} \text { in the } \\
\text { normal care group; } 2.5 \mathrm{~kg} \text { in the group that received } \\
\text { regular nursing support; } 2.3 \mathrm{~kg} \text { in the group with web- } \\
\text { based intervention only; and } 4.31 \mathrm{~kg} \text { in the group with } \\
\text { web-based intervention and basic nursing support group. }\end{array}$ \\
\hline $\begin{array}{l}\text { Döring et al., } \\
2014^{(2)} \\
\text { Sweden }\end{array}$ & $\begin{array}{l}\text { Clinical trial, } \\
\text { randomized } \\
\mathrm{n}=43\end{array}$ & $\begin{array}{l}\text { Nursing intervention program with parents to } \\
\text { prevent child obesity, starting when the child is } \\
9-10 \text { months old and ending at } 4 \text { years of age. }\end{array}$ & $\begin{array}{l}\text { The BMI and waist measurement of the children at } 4 \text { years } \\
\text { old were significantly reduced. The secondary results } \\
\text { showed improvements in eating habits and physical activity } \\
\text { of children and mothers. }\end{array}$ \\
\hline $\begin{array}{l}\text { Hansson et } \\
\text { al., } 2011^{(25)} \\
\text { Sweden }\end{array}$ & $\begin{array}{l}\text { Observational, } \\
\text { phenomenological } \\
\mathrm{n}=20\end{array}$ & $\begin{array}{l}\text { Semi-structured interviews to understand the views } \\
\text { of physicians and nurses in relation to the care of } \\
\text { people with obesity. }\end{array}$ & $\begin{array}{c}\text { The general view of the team was that obesity should } \\
\text { be prioritized in PHC, but they did not consider it the } \\
\text { responsibility of this level of care, since they did not } \\
\text { consider it to be a disease. Nevertheless, the team felt } \\
\text { it was important for patients to receive personalized } \\
\text { guidelines. }\end{array}$ \\
\hline $\begin{array}{l}\text { Phillips et } \\
\text { al., 2014(26) } \\
\text { Wales }\end{array}$ & $\begin{array}{l}\text { Observational, } \\
\text { descriptive } \\
\mathrm{n}=18\end{array}$ & $\begin{array}{l}\text { Semi-structured interviews with nurses about } \\
\text { good practices and barriers perceived by these } \\
\text { professionals when dealing with obesity in PHC. }\end{array}$ & $\begin{array}{l}\text { Nurses provided regular care to people suffering from } \\
\text { obesity associated with other comorbidities. They had } \\
\text { mixed opinions on how to approach the subject of obesity } \\
\text { with people considered to be healthy. }\end{array}$ \\
\hline $\begin{array}{l}\text { Gorin et al., } \\
2014^{(27)} \\
\text { USA }\end{array}$ & $\begin{array}{l}\text { Clinical trial, } \\
\mathrm{n}=150\end{array}$ & $\begin{array}{l}\text { Families with children from } 2 \text { to } 4 \text { years of age, } \\
\text { that received brief counseling by physicians } \\
\text { and nurses for } 12 \text { months (Group 1); monthly } \\
\text { counseling and phone calls (Group 2); monthly } \\
\text { counseling and home visits (Group 3). }\end{array}$ & $\begin{array}{l}\text { The interventions led to a reduction in the percentile of } \\
\text { children, with better results when the families received } \\
\text { counseling and home visits. }\end{array}$ \\
\hline $\begin{array}{l}\text { Marcos et } \\
\text { al., } 2014^{(28)} \\
\text { Spain }\end{array}$ & $\begin{array}{l}\text { Multicenter trial, } \\
\text { randomized } \\
\mathrm{n}=696\end{array}$ & $\begin{array}{l}\text { A group of adults with obesity received counseling } \\
\text { regarding change of habits in order to lose weight, } \\
\text { from nurses with the support of a psychologist; the } \\
\text { other group received routine monitoring. }\end{array}$ & $\begin{array}{l}\text { The mean weight loss percentage was } 1 \% \text { for the control } \\
\text { group and } 2.5 \% \text { in the intervention group; } 18.1 \% \text { of the } \\
\text { control group reduced their weight by more than } 5 \% \text {, } \\
\text { compared to } 26.9 \% \text { in the intervention group. After two } \\
\text { years, the mean BMl of the control group dropped } 0.9 \mathrm{~kg} / \\
\mathrm{m}^{2} \text {, as opposed to } 2.4 \mathrm{~kg} / \mathrm{m}^{2} \text { in the intervention group. }\end{array}$ \\
\hline $\begin{array}{l}\text { Redsell et } \\
\text { al., } 2011^{(29)} \\
\text { England }\end{array}$ & $\begin{array}{l}\text { Observational, } \\
\text { mixed methods } \\
\mathrm{n}=8\end{array}$ & $\begin{array}{l}\text { Semi-structured interviews with } 12 \text { physicians } \\
\text { and six nurses to identify knowledge, beliefs, and } \\
\text { practices in relation to child obesity. }\end{array}$ & $\begin{array}{l}\text { The physicians were less confident to give advice on } \\
\text { children's nutrition than nurses, but they were more } \\
\text { knowledgeable about the health risks of obesity. }\end{array}$ \\
\hline $\begin{array}{l}\text { Thabault et } \\
\text { al., } 2016^{(30)} \\
\text { USA }\end{array}$ & $\begin{array}{c}\text { Observational, } \\
\text { descriptive } \\
\mathrm{n}=38\end{array}$ & $\begin{array}{l}\text { Motivational interventions carried out by nurses } \\
\text { with adults with obesity in relation to changes in } \\
\text { eating habits and encouragement to exercise. }\end{array}$ & $\begin{array}{l}\text { The interventions of the nurses resulted in actual weight } \\
\text { loss ( } 3.03 \mathrm{~kg} \text { after four visits and } 4.85 \mathrm{~kg} \text { after eight } \\
\text { visits); } 39 \% \text { of the adults lost } 5 \% \text { or more weight at the } \\
\text { end of } 12 \text { weeks. }\end{array}$ \\
\hline $\begin{array}{l}\text { Derksen et } \\
\text { al., } 2012^{(31)} \\
\text { Holland }\end{array}$ & $\begin{array}{l}\text { Observational, } \\
\text { descriptive } \\
\mathrm{n}=29 \text { professionals } \\
\mathrm{n}=24 \text { users }\end{array}$ & $\begin{array}{l}\text { Three focus groups with adults were created } \\
\text { with semi-structured interviews with health } \\
\text { professionals to understand experiences related } \\
\text { to obesity prevention, diagnosis, treatment and } \\
\text { relapse prevention. }\end{array}$ & $\begin{array}{l}\text { The users felt that the professionals offered contradictory } \\
\text { advice and recommendations which did not meet their } \\
\text { needs, and did not provide support. Professionals felt lack } \\
\text { of qualification to support and motivate adults since they } \\
\text { did not consider obesity to be a chronic disease. }\end{array}$ \\
\hline $\begin{array}{l}\text { Isma et al., } \\
2012^{(32)} \\
\text { Sweden }\end{array}$ & $\begin{array}{l}\text { Observational, } \\
\text { phenomenological } \\
\mathrm{n}=18\end{array}$ & $\begin{array}{l}\text { Semi-structured interviews with nurses to identify } \\
\text { their views on child overweight and obesity. }\end{array}$ & $\begin{array}{l}\text { Overweight in younger children was overlooked by } \\
\text { professionals and viewed as a consequence of their } \\
\text { parents' lifestyle, with not much importance attached to it } \\
\text { in the preschool period. }\end{array}$ \\
\hline $\begin{array}{l}\text { Kelishadi et } \\
\text { al., } 2012^{(33)} \\
\text { Iran }\end{array}$ & $\begin{array}{l}\text { Non-randomized } \\
\text { clinical trial } \\
\mathrm{n}=457\end{array}$ & $\begin{array}{l}\text { Interventions carried out by physicians and nurses } \\
\text { with children and adolescents suffering from } \\
\text { obesity associated with other comorbidities. }\end{array}$ & $\begin{array}{l}\text { There was a significant decrease in the anthropometric } \\
\text { and cardiometabolic risk measurements, as well as an } \\
\text { increase in HDL-C. The prevalence of metabolic syndrome } \\
\text { decreased by } 20.8 \% \text {. }\end{array}$ \\
\hline $\begin{array}{l}\text { Korhonen et } \\
\text { al., } 2014^{(34)} \\
\text { Finland }\end{array}$ & $\begin{array}{l}\text { Longitudinal } \\
\text { cohort study } \\
\mathrm{n}=906\end{array}$ & $\begin{array}{c}\text { Assessment of interventions based on lifestyle } \\
\text { advice given by a nurse over a period of three } \\
\text { years, with people between } 45 \text { and } 70 \text { years of age } \\
\text { with overweight and comorbidities. }\end{array}$ & $\begin{array}{l}\text { Around } 18 \% \text { of the individuals lost at least } 5 \% \text { of their } \\
\text { starting weight and managed to maintain the results for } \\
\text { three years; } 70 \% \text { were able to stabilize their weight after } \\
\text { the intervention. }\end{array}$ \\
\hline $\begin{array}{l}\text { Engström et } \\
\text { al., } 2013^{(35)} \\
\text { Sweden }\end{array}$ & $\begin{array}{l}\text { Observational, } \\
\text { descriptive } \\
\mathrm{n}=247\end{array}$ & $\begin{array}{l}\text { Questionnaires with nurses for describing self- } \\
\text { reported clinical activities, opinions, and attitudes } \\
\text { in relation to obesity management. }\end{array}$ & $\begin{array}{c}\text { The nurses gave advice on physical activities }(40.1 \%) \\
\text { and lifestyle changes ( } 34.8 \%) ; 25 \% \text { rarely/never carried } \\
\text { out these activities, and } 78.1 \% \text { BMI or abdominal } \\
\text { circumference assessments. }\end{array}$ \\
\hline $\begin{array}{l}\text { Ritten et al., } \\
2016^{(36)} \\
\text { USA }\end{array}$ & $\begin{array}{l}\text { Observational, } \\
\text { descriptive } \\
\mathrm{n}=16\end{array}$ & $\begin{array}{l}\text { Adults received five home visits from a nurse } \\
\text { every two weeks for three months, with behavioral } \\
\text { interventions. }\end{array}$ & $\begin{array}{l}\text { It was noted that the participants took greater responsibility } \\
\text { for their health, physical activities, nutrition, spiritual } \\
\text { growth, stress management and motivation to live healthily. } \\
\text { Systemic blood pressure and BMI decreased significantly. }\end{array}$ \\
\hline $\begin{array}{l}\text { Gunther et } \\
\text { al., } 2012^{(37)} \\
\text { England }\end{array}$ & $\begin{array}{l}\text { Observational, } \\
\text { descriptive } \\
n=23\end{array}$ & $\begin{array}{l}\text { Semi-structured interviews with seven physicians, } \\
\text { seven nurses and nine overweight adults to } \\
\text { describe difficulties and ease in implementing } \\
\text { obesity management recommendations. }\end{array}$ & $\begin{array}{l}\text { The difficulties included stigma, previous treatment } \\
\text { experiences, professionals not wanting to assume } \\
\text { responsibility for obesity management, lack of care } \\
\text { consistency, and limited skills of the professionals. Trust } \\
\text { in the professional-patient relationship was considered } \\
\text { to be easy. }\end{array}$ \\
\hline $\begin{array}{l}\text { Sousa et al., } \\
2015^{(38)} \\
\text { Brazil }\end{array}$ & $\begin{array}{c}\text { Observational, } \\
\text { descriptive } \\
\mathrm{n}=10\end{array}$ & $\begin{array}{l}\text { Semi-structured interviews with ten primary care } \\
\text { nurses to obtain their views on child obesity. }\end{array}$ & $\begin{array}{l}\text { The nurses had knowledge about changes in the nutritional } \\
\text { profile of children, as well as the causes and consequences } \\
\text { of obesity. They reported encouraging physical activities, } \\
\text { moderate use of technologies, and nutritional education. }\end{array}$ \\
\hline
\end{tabular}

Continue 


\begin{tabular}{|c|c|c|c|}
\hline $\begin{array}{l}\text { Ware et al., } \\
2012^{(39)} \\
\text { England }\end{array}$ & $\begin{array}{l}\text { Observational, } \\
\text { descriptive } \\
n=36\end{array}$ & $\begin{array}{l}\text { Focus groups to assess interventions by physicians, } \\
\text { nurses and nursing aides over a period of six } \\
\text { months, using in-person meetings, email or } \\
\text { telephone calls to change behaviors. }\end{array}$ & $\begin{array}{c}\text { Although considered an additional workload, the web } \\
\text { program was viewed by the health professionals as a } \\
\text { possibility for providing continuity of care. }\end{array}$ \\
\hline $\begin{array}{l}\text { Findholt et } \\
\text { al., } 2013^{(40)} \\
\text { USA }\end{array}$ & $\begin{array}{l}\text { Observational, } \\
\text { descriptive } \\
n=13\end{array}$ & $\begin{array}{c}\text { Semi-structured interviews with eight } \\
\text { physicians and five nurses to understand the } \\
\text { problems that affect child obesity management } \\
\text { in a rural community. }\end{array}$ & $\begin{array}{l}\text { They indicated the following barriers: time restrictions, } \\
\text { limited knowledge, and lack of specialists and } \\
\text { multidisciplinary care services. The professionals expressec } \\
\text { interest in receiving training. }\end{array}$ \\
\hline $\begin{array}{l}\text { Little et al., } \\
2016^{(41)} \\
\text { England }\end{array}$ & $\begin{array}{l}\text { Controlled trial, } \\
\text { randomized } \\
\mathrm{n}=818\end{array}$ & $\begin{array}{c}\text { Online intervention with } 24 \text { web-based } \\
\text { sessions, over a period of six months, on weight } \\
\text { control associated with brief nursing support } \\
\text { and phone calls. }\end{array}$ & $\begin{array}{l}\text { The control group lost almost } 3 \mathrm{~kg} \text { in } 12 \text { months and } \\
21 \% \text { maintained a } 5 \% \text { weight reduction in the } 12^{\text {th }} \\
\text { month. In the intervention group, there was an additional } \\
\text { weight reduction of } 1.5 \mathrm{~kg} \text { and } 29 \% \text { maintained } \\
\text { the weight in the } 12^{\text {th }} \text { month. }\end{array}$ \\
\hline
\end{tabular}

\section{DISCUSSION}

\section{TheMe 1 - COUNSELING AIMED AT WEIGHT CONTROL AND PROMOTION OF HEALTHY LIFESTYLE HABITS}

PHC professionals regularly have opportunities to address obesity, by providing counsel on nutrition and physical activities and answering questions about this chronic disease $^{(38,42)}$. This professional activity is considered indispensable in PHC in the National Health Promotion Policy ${ }^{(42)}$.

Providing health counseling is important for promoting healthy habits, which include weight loss, physical activity and changes in eating habits ${ }^{(42)}$. In this context, families need to be the focus of actions aimed at present and future improvements, especially children and communities, based on the fact that when parents and/or guardians are approached, changes in behavior tend to be possible ${ }^{(24,27)}$.

Nutritional status, especially in the first year of life, is a determining factor for children's health. The initial stages of human development are essential for determining health conditions in the long term and have a direct impact on adult life ${ }^{(11)}$. The studies reviewed indicated that childhood-focused health advice from nurses was given primarily during childcare consultations and home visits, and was also directed toward parents. The content of this advice involved relevant aspects of children's nutrition for obesity prevention, amount of time spent in physical activities and family habits ${ }^{(11,18,27,33)}$.

Interventions by $\mathrm{PHC}$ nurses with parents of children in their first year of life were able to reduce BMI and the waist measurement of children, as well as improve nutritional habits, physical activity and the BMI of the moth$\mathrm{ers}^{(24)}$. Families were also instructed by nurses to increase their fruit and vegetable consumption, reduce the number of hours watching television and increase the number of hours of physical activities ${ }^{(18)}$.

On the other hand, a study showed that nurses never/ rarely used growth charts to identify babies or children at risk of overweight/obesity, and less than half regularly promoted physical activities and discuss with parents or guardians the effects of sedentary lifestyles ${ }^{(11,35)}$. The results of the nursing interventions were more significant the longer they were, showing that the effects may take longer to emerge, but are effective, especially if the interventions occur over the long term ${ }^{(13,18,24)}$.
When the target audience of the interventions was adolescents with obesity, the studies indicated that lack of faceto-face contact between these users and PHC nurses was an obstacle. The use of technologies, such as interventions based on motivational techniques via web was an important tool for reaching this group. These interventions were able to achieve positive results in terms of improved cardiorespiratory fitness, weight control and quality of life of these adolescents ${ }^{(14)}$.

The use of technology, combined with counseling from nurses, can produce better weight loss results than those achieved solely through web-based management programs or conventional nursing care. This suggests that the combination of web-based interventions with basic nursing support can provide effective weight management solutions in the context of $\mathrm{PHC}^{(23,41)}$.

Interventions carried out by nurses through nursing consultations combined with telephone calls resulted in overall high satisfaction of adults suffering from obesity. Even though appreciative of the phone calls, they preferred face-to-face contact and viewed nurses as professionals qualified to carry out health education activities and motivational interventions ${ }^{(13)}$. In conventional care, $\mathrm{PHC}$ nursing consultations are an ideal time to provide health advice on overweight and obesity to users and, through this strategy, nurses obtain input for decision making, planning, and assessment of actions targeting individuals, families and the community ${ }^{(43)}$.

Two studies conducted in Holland examined 100 nursing consultations, in order to assess the information given by nurses to people with obesity and the type of communication used. The studies found that the advice focused on weight loss, nutritional guidance, and physical activity. However, the professionals did not address the difficulties involved in the weight loss process and did not continue to provide support through subsequent assessments. Most of the nurses used motivational communication to address weight and physical activity issues and informational communication for discussions on nutrition ${ }^{(4,10)}$. Other investigations also pointed out that motivational communication is an important strategy for tackling obesity prevention and treatment ${ }^{(27-28,30)}$. An American study found that adults with obesity assumed greater responsibility for their health after behavioral interventions in the form of house visits by a nurse ${ }^{(36)}$. 
Studies on interventions with people with obesity involving multiprofessional teams indicated positive results in relation to the work of nurses. In community contexts in Italy, specially trained nurses were more effective than physicians in carrying out self-management support interventions for people with obesity associated with diabetes and cardiovascular diseases, in terms of systemic blood pressure control and reduction of glycated hemoglobin ${ }^{(44)}$.

In Holland, software-based guidelines given by PHC nurses were able to generate better results in relation to weight loss and reduced fasting blood glucose than in groups that received conventional guidelines from general practitioners ${ }^{(12)}$. The combination of brief nursing support with online sessions generated higher weight loss in adults in England ${ }^{(41)}$.

The studies reviewed showed that interventions carried out by $\mathrm{PHC}$ nurses with people suffering from obesity were more frequent in the presence of comorbidities. In Wales, the activities of these professionals focused more on groups of people with obesity with high blood pressure and diabetes ${ }^{(26)}$. In Iran, children and adolescents suffering from obesity and comorbidities who were monitored by nurses for 24 weeks, experienced a decrease in anthropometric measurements, an increase in HDL-cholesterol, and a decrease in the prevalence of metabolic syndrome by $20.8 \%{ }^{(33)}$. In Finland, most overweight adults with associated comorbidities managed to stabilize their weight after an intervention based on lifestyle-change counseling during a period of three years ${ }^{(34)}$.

These findings demonstrate the relevance of nursing interventions in the care of people with obesity in all stages of human development and reaffirm the commitment of these professionals to the health-disease process of individuals. Therefore, it is necessary to concretely incorporate guidelines into PHC that orient nursing practices to coordinate the care of people suffering from obesity, even when they require care in other levels of the health system ${ }^{(3)}$.

\section{Theme II - Perception of Primary Health Care NURSES IN RELATION TO INTERVENTIONS WITH PEOPLE WITH OBESITY}

Studies that sought to identify the perception of professionals from multidisciplinary teams, among them nurses, regarding actions in PHC settings directed toward people with obesity, listed facilitators and barriers in relation to approaching these people.

Facilitators included confidence in their own communication skills, ability to build relationships with users, participation in training, and receiving more institutional support to invest more time in caring for people with obesity $^{(21)}$. These skills, which are inherent to nursing, especially communication, should be promoted in PHC, since they facilitate the first access of users with obesity to health services and encourage care continuity for monitoring their health status.

Among the barriers, the nurses highlighted lack of uniformity in obesity prevention and control guidelines, as well as inadequate management of the services. They also noted the need for knowledge about this chronic disease, responsibility, and cooperation among health team members ${ }^{(15)}$.
In a study conducted in London, nurses commented on structural weaknesses in health services that hindered caring for users with obesity, such as materials and equipment incompatible with the body structure of overweight people. In relation to management problems, nurses felt there was a lack of priority in obesity management, shortage of time in the workday, heavy workloads, and lack of clarity regarding protocols and roles for guiding clinical actions ${ }^{(21)}$.

For PHC to achieve effective results in obesity control, it is essential to coordinate care among managers and health professionals. In this regard, care planning for individuals with obesity must ensure adequate infrastructure in PHC units, such as access ramps, wide doors, chairs, stretchers, scales with a capacity for over $200 \mathrm{~kg}$, specific sphygmomanometers and other items. In addition, health professionals must strive to adopt care guidelines for these people ${ }^{(45)}$.

Some of the studies reviewed mentioned that health team professionals had limited knowledge about obesity ${ }^{(15,17,21-22,37)}$. Research in Australia found that nurses were interested in participating in training aimed at child obesity prevention ${ }^{(17)}$. A study conducted with Brazilian nurses also showed that these professionals had knowledge about changes in the nutritional profiles of children, and the causes and consequences of obesity ${ }^{(38)}$.

Lack of training of teams can be an impediment in caring for people with obesity, since PHC professionals must be qualified and sensitized to perceive and efficiently address this need ${ }^{(45)}$.

In both Wales and Sweden, PHC nurses carried out weight control activities with users suffering from obesity, in case there was an associated comorbidity. Some reported frustration in dealing with these users, especially those with a high level of obesity, due to high rates of abandonment of treatment and little actual weight loss, in addition to the fact that the obesity of these users discouraged nurses from approaching them ${ }^{(25-26)}$.

It is also very important for PHC nurses to consider their responsibility toward obesity, regardless of whether users have comorbidities or not. According to the National Basic Care Policy, actions should focus on obesity risk stratification and health promotion activities for this population ${ }^{(3)}$. However, for those with comorbidities, nurses should focus even more on eating habits and physical activity, and in such cases, a cardiovascular assessment - an important tool for understanding the risk of occurrence of an acute event - is essential ${ }^{(45)}$.

Also worth noting is the belief that obesity is the responsibility of the family and the individual. A study that involved family physicians, nutritionists and nurses in Portugal showed that professionals had negative attitudes toward people with obesity. They were described as unmotivated and passive in relation to treatment. Family doctors had low success expectations and were frustrated by the lack of adherence of users, which led them to adopt a passive and resigned attitude toward treatment. However, nutritionists and nurses felt more motivated to approach these users, despite understanding the difficulties involved with obesity control ${ }^{(16)}$. Australian nurses also referred the lack of confidence in the work carried out with people suffering from obesity ${ }^{(17)}$. In Sweden, nurses did not always assign importance to overweight in children and considered it to be a consequence of their parents' lifestyle ${ }^{(32)}$. 
The difficulties pointed out by nurses in working with people with obesity, besides the increase in chronic conditions in PHC, makes it imperative to consider restructuring services at this level of care, accompanied by a training and awareness-raising process focused on providing comprehensive care to people with obesity. This restructuring, as well as behavioral changes in the actors involved in the care - managers, professionals and users - is necessary in order to provide quality health care for these individuals ${ }^{(45)}$.

A limitation of this study is the fact that it encompassed studies conducted in different countries where government investments and public policies generate different realities in terms of $\mathrm{PHC}$ and professional training. These factors can have an influence on nursing interventions with people suffering from obesity. Therefore, the analysis may not have covered all the specificities of the practices in the context in which these professionals were inserted.

The contribution of this literature review to nursing was the identification of knowledge produced about PHC nursing interventions with people with obesity, in a worldwide context, which may help improve the health care given to this segment of the population and encourage scientific production in the field of nursing.

The results presented may prompt reflections in terms of professional training, management and health services, regarding the importance of nurses to use digital technologies, motivational techniques and nursing consultations as they work with people with obesity in PHC. This could help assign greater relevance to their actions in the multiprofessional teams in which they participate at this health care level.

\section{CONCLUSION}

The knowledge produced in the literature on PHC nursing interventions with people suffering from obesity showed that these professionals use technologies based on digital resources, motivational techniques and nursing consultations to provide health counseling for children and family members, adolescents and adults with obesity, with or without comorbidities. The content of the nursing interventions included dietary aspects for child obesity prevention, the importance of physical activity and healthy eating habits.

It also revealed that the perception of PHC nurses regarding interventions with people with obesity focuses on the difficulties in caring for these users. These include lack of time and resources in PHC units, as well as insufficient knowledge of the issues associated with obesity. As a result, professionals do not always prioritize actions in relation to this public. On the other hand, confidence in communication skills and the ability to create bonds with users are factors that facilitate approaching these people. These aspects require ongoing education.

It is expected that the results of this study will encourage further research to be conducted, especially in Brazil, whose scientific production on $\mathrm{PHC}$ nursing interventions with people suffering from obesity is still in the initial stages. This could provide a foundation for evidence-based nursing practices for this public.

\section{RESUMO}

Objetivo: Identificar o conhecimento produzido sobre as intervenções do enfermeiro às pessoas com obesidade na Atenção Primária à Saúde. Método: Revisão integrativa da literatura de publicações indexadas nas bases de dados: CINAHL, LILACS, MEDLINE, SciELO, SCOPUS e WEB OF SCIENCE, entre 2011 e 2016. Resultado: Foram selecionados 33 artigos. O conhecimento produzido congregou dois temas: "Aconselhamento visando ao controle do peso corporal e à promoção de hábitos saudáveis de vida" e "Percepção do enfermeiro sobre as intervenções às pessoas com obesidade na Atenção Primária à Saúde”. Conclusão: Os resultados poderão contribuir para a reflexão no âmbito da formação profissional, gestão e serviços de saúde acerca da relevância de o enfermeiro atuar junto às pessoas com obesidade, com o aporte de tecnologias digitais, técnicas motivacionais e da consulta de enfermagem. Isso poderá estimular a valorização de suas ações na equipe multiprofissional da qual é integrante nesse nível de atenção à saúde.

\section{DESCRITORES}

Obesidade; Cuidados de Enfermagem; Enfermagem de Atenção Primária; Revisão.

\section{RESUMEN}

Objetivo: Identificar el conocimiento producido acerca de las intervenciones del enfermero en las personas con obesidad en la Atención Primaria de Salud. Método: Revisión integrativa de la literatura de publicaciones indexadas en las bases de datos: CINAHL, LILACS, MEDLINE, SciELO, SCOPUS y WEB OF SCIENCE, entre 2011 y 2016. Resultado: Fueron seleccionados 33 artículos. El conocimiento producido congregó dos temas: "Aconsejamiento con vistas al control del peso corporal y la promoción de hábitos sanos de vida" y "Percepción del enfermero acerca de las intervenciones en las personas con obesidad en la Atención Primaria de Salud". Conclusión: Los resultados podrán contribuir a la reflexión en el marco de la formación profesional, gestión de servicios sanitarios acerca de la relevancia de la actuación del enfermero junto a las personas con obesidad, con el aporte de tecnologías digitales, técnicas motivacionales y la consulta de enfermería. Eso podrá estimular la valoración de sus acciones en el equipo multiprofesional del que es integrante en ese nivel de atención sanitaria.

\section{DESCRIPTORES}

Obesidad; Atención de Enfermería; Enfermería de Atención Primaria; Revisión. 


\section{REFERENCES}

1. World Health Organization. Obesity and overweight [Internet]. Geneva: WHO; 2016. [cited 2017 Mar 14]. Available from: http://www. who.int/mediacentre/factsheets/fs311/en/

2. Brasil. Ministério da Saúde; Agência Nacional de Saúde Suplementar. Vigitel Brasil 2015. Saúde Suplementar: vigilância de fatores de risco e proteção para doenças crônicas por inquérito telefônico [Internet]. Brasília: MS; 2017. [citado 2017 mar. 14]. Disponível em: http:// www.ans.gov.br/images/stories/Materiais_para_pesquisa/Materiais_por_assunto/2015_vigitel.pdf

3. Brasil. Ministério da Saúde; Secretaria de Atenção à Saúde, Departamento e Atenção Básica. Política Nacional de Atenção Básica [Internet] Brasília: MS; 2012. [citado 2017 mar. 14]. Disponível em: http://189.28.128.100/dab/docs/publicacoes/geral/pnab.pdf

4. van Dillen SM, Noordman J, van Dulmen S, Hiddink GJ. Quality of weight-loss counseling by Dutch practice nurses in primary care: an observational study. Eur J Clin Nutr. 2015;69(1):73-8. DOI: 10.1038/ejcn.2014.129

5. Sargent GM, Forrest LE, Parker RM. Nurse delivered lifestyle interventions in primary health care to treat chronic disease risk factors associated with obesity: a systematic review. Obes Rev [Internet]. 2012 [cited 2017 Mar 15];13(12):1148-71. Available from: https://www. ncbi.nlm.nih.gov/pmc/articles/PMC3533768/

6. van Dillen SM, Hiddink GJ. To what extent do primary care practice nurses act as case managers lifestyle counselling regarding weight management? A systematic review. BMC Fam Pract [Internet]. 2014 [cited 2017 Mar 15];15:197. Available from: https://doi.org/10.1186/ s12875-014-0197-2

7. Soares CB, Hoga LAK, Peduzzi MSC, Yonekura T, Silva DRAD. Integrative review: concepts and methods used in nursing. Rev EsC Enferm USP [Internet]. 2014 Apr [cited 2017 Mar 15];48(2):329-39. Available from: http://www.scielo.br/pdf/reeusp/v48n2/0080-6234reeusp-48-02-335.pdf

8. Milner KA, Cosme S. The PICO Game: an innovative strategy for teaching step 1 in evidence-based practice. Worldviews Evid Based Nurs. 2017 Aug 11. [Epub ahead of print]

9. United Nations. General Assembly. Political Declaration of the High-Level Meeting of the General Assembly on the Prevention and Control of non Communicable Diseases [Internet]. Geneva: WHO; 2011 [cited 2017 Mar 14] Available from: http://www.who.int/nmh/events/ un_ncd_summit2011/political_declaration_en.pdf

10. van Dillen SM, Noordman J, van Dulmen S, Hiddink GJ. Examining the content of weight, nutrition and physical activity advices provided by Dutch practice nurses in primary care: analysis of videotaped consultations. Eur J Clin Nutr. 2014;68(1):50-6. DOI: 10.1038/ejcn.2013.219

11. Laws R, Campbell KJ, van der Pligt P, Ball K, Lynch J, Russell G, et al. Obesity prevention in early life: an opportunity to better support the role of maternal and child health nurses in Australia. BMC Nurs [Internet]. 2015 [cited 2017 Mar 15];14:26. Available from: https://www. ncbi.nlm.nih.gov/pmc/articles/PMC4429503/

12. Bogt NCW, Bemelmans WJ, Beltman FW, Broer J, Smit AJ, Meer K. Preventing weight gain by lifestyle intervention in a general practice setting. Arch Intern Med. 2011;171(4):306-13. DOI: 10.1001/archinternmed.2011.22

13. Barte JCM, Bogt NCW, Beltman FW, Meer K, Bemelmans WJE. Process evaluation of a lifestyle intervention in primary care: implementation issues and the participants' satisfaction of the GOAL study. Health Educ Behav. 2012;39(5):564-73. DOI:10.1177/1090198111422936

14. Riiser K, Londal K, Ommundsen Y, Smastuen MC, Misvaer N, Helseth S. The outcomes of a 12-week internet intervention aimed at improving fitness and health-related quality of life in overweight adolescents: the young \& active controlled trial. PLoS One [Internet]. 2014 [cited 2017 Mar 15];9:12:e114732. Available from: https://www.ncbi.nlm.nih.gov/pmc/articles/PMC4257715/

15. Isma GE, Bramhagen AC, Alhtrom G, Ostman M, Dykes AK. Obstacles to the prevention of overweight and obesity in the context of child health care in Sweden. BMC Fam Pract [Internet]. 2013 [cited 2017 Mar 15];14:143. Available from: https://www.ncbi.nlm.nih.gov/pmc/ articles/PMC3852529/

16. Teixeira F, Pais-Ribeiro JL, Maia A. Uns desistem, outros insistem: semelhanças e diferenças no discurso de profissionais de saúde face à obesidade. Rev Port Sau Pub [Internet]. 2015 [citado 2017 mar. 15];33(2):137-47. Disponível em: http://www.scielo.mec.pt/pdf/rpsp/ v33n2/v33n2a03.pdf

17. Robinson A, Denney-Wilson E, Laws R, Harris M. Child obesity prevention in primary health care: investigating practice nurse roles, attitudes and current practices. J Paediatr Child Health. 2013;49(4):E294-9. DOI: 10.1111/jpc.12164

18. Tucker SJ, Ytterber KL, Lenoch LM, Schmit TL, Mucha DI, Wooten JA, et al. Reducing pediatric overweight: nurse-delivered motivational interviewing in primary care. J Pediatr Nurs. 2013;28(6):536-47. DOI: 10.1016/j.pedn.2013.02.031

19. Jarl J, Tolentino JC, James K, Clark MJ, Ryan M. Supporting cardiovascular risk reduction in overweight and obese hypertensive patients through DASH diet and lifestyle education by primary care nurse practitioners. J Am Assoc Nurse Pract. 2014;26(9):498-503. DOI: $10.1002 / 2327-6924.12124$

20. Karnon J, Afzali HHA, Gray J, Holton C, Banham D, Beilby J. A risk adjusted cost-effectiveness: analysis of alternative models of nurse involvement in obesity management in primary care. Obesity. 2013;21(3):472-9. DOI: 10.1002/oby.20100

21. Nolan C, Deehan A, Wylie A, Jones R. Practice nurses and obesity: professional and practice-based factors affecting role adequacy and role legitimacy. Prim Health Care Res Dev. 2012;13(4):353-63. DOI: 10.1017/S1463423612000059

22. Blackburn M, Stathi A, Keogh E, Eccleston C. Raising the topic of weight in general practice: perspectives of GPs and primary care nurses. BMJ Open. 2015;5(8):e008546. DOI: 10.1136/bmjopen-2015-008546

23. Yardley L, Ware LJ, Smith ER, Williams S, Bradbury KJ, Arden-Close EJ, et al. Randomised controlled feasibility trial of a web-based weight management intervention with nurse support for obese patients in primary care. Int J Behav Nutr Phys Act [Internet]. 2014 [cited 2017 Mar 15];11:67. Available from: https://www.ncbi.nlm.nih.gov/pmc/articles/PMC4045942/

24. Döring N, Hansson LM, Andersson ES, Bohman B, Westin M, Magnusson M, et al. Primary prevention of childhood obesity through counselling sessions at Swedish child health centres: design, methods and baseline sample characteristics of the PRIMROSE clusterrandomised trial. BMC Public Health [Internet]. 2014 [cited 2017 Mar 15];14:335. Available from: https://www.ncbi.nlm.nih.gov/pmc/ articles/PMC3995501/ 
25. Hansson LM, Rasmussen F, Ahlstrom GI. General practitioners' and district nurses' conceptions of the encounter with obese patients in primary health care. BMC Fam Pract [Internet]. 2011 [cited 2017 Mar 15];12. Available from: https://www.ncbi.nlm.nih.gov/pmc/articles/ PMC3050702/

26. Phillips K, Wood F, Kinnersley P. Tackling obesity: the challenge of obesity management for practice nurses in primary care. Fam Pract. 2014;31(1):51-9. DOI: 10.1093/fampra/cmt054

27. Gorin AA, Wiley J, Ohannessian CM, Hernandez D, Grant A, Michelle, et al. Steps to Growing Up Healthy: a pediatric primary care based obesity prevention program for young children. BMC Public Health [Internet]. 2014 [cited 2017 Aug 16];14(72): 90-7. Available from: https://www.ncbi.nlm.nih.gov/pmc/articles/PMC3933325/

28. Marcos MLT, Rosich N, Royo JMP, Casas AG, Selva JPS, Rodríguez-Montes JA, et al. Eficacia de las estrategias de motivación en el tratamiento del sobrepeso y obesidad. Nutr Hosp [Internet]. 2014 [citado 2017 ago. 16];30(4):741-8. Disponible en: http://www. aulamedica.es/nh/pdf/7704.pdf

29. Redsell SA, Atkinson PJ, Nathan D, Siriwardena NA, Swift JA, Glazebrook C. Preventing childhood obesity during infancy in UK primary care: a mixed-methods study of HCPs' knowledge, beliefs and practice. BMC Fam Pract [Internet]. 2011 [cited 2017 Aug 16];12:54. Available from: https://www.ncbi.nlm.nih.gov/pmc/articles/PMC3155826/

30. Thabault PJ, Burke PJ, Ades PA. Intensive behavioral treatment weight loss program in an adult primary care practice. J Am Assoc Nurse Pract. 2016;28(5):249-57.

31. Derksen RE, Brink-Melis WJ, Westerman MJ, Dam JJ, Seidell JC, Visscher TL. A local consensus process making use of focus groups to enhance the implementation of a national integrated health care standard on obesity care. Fam Pract. 2012;29 Suppl1:i177-84.

32. Isma GE, Bramhagen AC, Ahlstrom G, Ostman M, Dykes AK. Swedish Child Health Care nurses conceptions of overweight in children: a qualitative study. BMC Fam Pract [Internet]. 2012 [cited 2017 Aug 16];14(1):13-57. Available from: https://www.ncbi.nlm.nih.gov/pmc/ articles/PMC3426496/

33. Kelishadi R, Malekahmadi M, Hashemipour M, Soghrati M, Soghrati M, Mirmoghtadaee P, et al. Can a trial of motivational lifestyle counseling be effective for controlling childhood obesity and the associated cardiometabolic risk factors? Pediatr Neonatol. 2012;52(2):90-7.

34. Korhonen PE, Järvenpää S, Kautiainen H. Primary care-based, targeted screening programme to promote sustained weight management. Scand J Prim Health Care [Internet]. 2014 [cited 2017 Aug 16];32(1):30-6. Available from: https://www.ncbi.nlm.nih.gov/pmc/articles/ PMC4137900/

35. Engström M, Skytt B, Ernesäter A, Fläckman B, Mamhidir AG. District nurses' self-reported clinical activities, beliefs about and attitudes towards obesity management. Appl Nurs Res. 2013;26(4):198-203.

36. Ritten A, Waldrop J, Kitson J. Fit living in progress--fighting lifelong obesity patterns (FLIP-FLOP): a nurse practitioner delivered intervention. Appl Nurs Res. 2016;30(1):119-24.

37. Gunther S, Guo F, Sinfield P, Rogers S, Baker R. Barriers and enablers to managing obesity in general practice: a practical approach for use in implementation activities. Qual Prim Care. 2012;20(2):93-103.

38. Sousa LAPA, Ascari RA, Ferraz L, Zanatta EA. Obesidade infantil: o olhar dos enfermeiros inseridos na atenção básica. Cult Cuidados [Internet] 2015 [citado 2017 ago. 16];19(41):147-56. Disponible en: https://rua.ua.es/dspace/bitstream/10045/46622/1/CulturaCuidados_41_17.pdf

39. Ware LJ, Williams S, Bradbury K, Brant C, Little P, Hobbs FD, et al. Exploring weight loss services in primary care and staff views on using a web-based programme. Inform Prim Care. 2012;20(4):283-8.

40. Findholt NE, Davis MM, Michael YL. Perceived barriers, resources, and training needs of rural primary care providers relevant to the management of childhood obesity. J Rural Health. 2013;29(1):17-24.

41. Little P, Stuart B, Hobbs FR, Kelly J, Smith ER, Bradbury KJ, et al. An internet-based intervention with brief nurse support to manage obesity in primary care (POWeR+): a pragmatic, parallel-group, randomised controlled trial. Lancet Diabetes Endocrinol. 2016;4(10):821-8.

42. Brasil. Ministério da Saúde. Política Nacional de Promoção da Saúde. Revisão da Portaria MS/GM n 687, de 30 de março de 2006 [Internet]. Brasília: MS; 2015 [citado 2017 mar. 14]. Disponível em: http://bvsms.saude.gov.br/bvs/publicacoes/pnps_revisao_portaria_687.pdf

43. Dantas CN, Santos VEP, Tourinho FSV. Nursing consultation as a technology for care in light of the thoughts of Bacon and Galimberti. Texto Contexto Enferm [Internet]. 2016 [cited 2017 Mar 14];25(1):e2800014. Available from: http://www.scielo.br/pdf/tce/v25n1/en_01040707-tce-25-01-2800014.pdf

44. Massimi A, De Vito C, Brufola I, Corsaro A, Marzuillo C, Migliara G, et al. Are community-based nurse-led self-management support interventions effective in chronic patients? Results of a systematic review and meta-analysis. PLoS One [Internet]. 2017 [cited 2017 Apr 13];12:3:e0173617. Available from: https://www.ncbi.nlm.nih.gov/pmc/articles/PMC5345844/

45. Brasil. Ministério da Saúde; Secretaria de Atenção à Saúde, Departamento de Atenção Básica. Estratégias para o cuidado da pessoa com doença crônica: obesidade. Brasília: MS; 2014. (Cadernos de Atenção Básica, n. 38). 